\title{
The revitalization of service orientation: a business services model
}

\author{
Albert Plugge \\ Delft University of Technology, Delft, Netherlands \\ Shahrokh Nikou \\ Abo Akademi University, Turku, Finland and \\ Stockholm University, Stockholm, Sweden, and \\ Harry Bouwman \\ Delft University of Technology, Delft, Netherlands
}

Revitalization of service orientation

Received 5 February 2020

Revised 22 May 2020

Accepted 22 May 2020

\begin{abstract}
Purpose - Due to the convergence of rapid business developments and digitization challenges, service orientation is back on the research agenda as a concept to improve firms' business services. Yet, little is known about the type of determinants that are relevant and to what degree they affect a firm's service-oriented strategy.

Design/methodology/approach - Building on structural equation modeling (SEM) and a unique data set of 131 international firms from different continents, the authors identify and analyze the key determinants in the context of a firm's service-oriented strategy.

Findings - The findings show that in order to cater for changes, organizations have to manage and adapt the coherence of the determinants' business services, business processes and knowledge sharing continuously. Moreover, the results show that a service-oriented strategy is not only influenced by business services as such, but business services mediate the relationships between business processes, governance and process-aware information systems to a service-oriented strategy.

Research limitations/implications - A limitation is imposed by the limited sample size and the unbalanced response of participants (executive management). In future research, a more extensive survey among a broader group of participants will help the authors to develop their model further in order to generalize the results, as well as more finely grained research related to geography and size might be pursued. Future empirical research is necessary to identify and test the relationships between other constructs and study their effect on a firm's service-oriented strategy.

Practical implications - On a practical level, the authors postulate that an organization's executive management should pay attention to invest in an organizational entity (department) that manages business services continuously. This organizational entity has to ensure that related processes and knowledge sharing are in place to establish and maintain a service-oriented strategy.

Originality/value - This research contributes to service-oriented literature by operationalizing the implementation of an organization's service-oriented strategy. The authors' insights go beyond the findings of Aier et al. (2011). The authors found that a service-oriented strategy influences service-oriented project success positively. The authors extended these findings, based on a unique data set, by studying business services and influencing determinants (i.e. business processes, governance, PAIS and knowledge sharing) within the context of service orientation. The renewed attention to the concept of service orientation provides insights into critical determinants that influence the implementation of a service-oriented strategy.
\end{abstract}

Keywords Governance, Organizational readiness, Business services, Business processes, Process-aware information systems, Service orientation

Paper type Research paper

(C) Albert Plugge, Shahrokh Nikou and Harry Bouwman. Published by Emerald Publishing Limited. This article is published under the Creative Commons Attribution (CC BY 4.0) licence. Anyone may reproduce, distribute, translate and create derivative works of this article (for both commercial and noncommercial purposes), subject to full attribution to the original publication and authors. The full terms of this licence may be seen at http://creativecommons.org/licences/by/4.0/legalcode

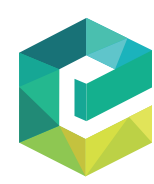

Business Process Management Journa Vol. 27 No. 8,2021 pp. $1-24$

Emerald Publishing Limited $1463-7154$ 
BPMJ

27,8

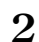

\section{Introduction}

Between 2005 and 2009, researchers paid ample attention to service orientation to improve internal business services by building these out of readily available building blocks (e.g. Cherbakov et al., 2005; Janssen and Joha, 2008; Aier et al., 2011). By adopting a serviceoriented strategy, organizations create internal business services that are modular, accessible and interoperable (Fremantle et al., 2002) and utilize the possibility to reuse existing components of internal services in business processes (Demirkan et al., 2007). As a result, organizations are potentially more responsive to changing business circumstances (Umar, 2005). The focus of this paper is not on business-to-end-user services, whether these end users are consumers or other businesses, but on business services that are used to support organizations' internal business processes, for example, Finance and Accounting (F\&A), Human Resources (HR), Procurement or IT services. Research interest to study the concept of service orientation, for example, service architectures and reuse of existing components as, for instance, offered by shared service centers, decreased after 2009, as the concepts of adaptability and agility were considered to be a serious alternative to respond to changes (Conboy, 2009). Due to the convergence of rapid business developments and digitization challenges, organizations nowadays again seek various approaches, which puts service orientation back in the limelight to achieve organizational responsiveness (Deloitte GBS, 2018; KPMG Insights, 2019). Market research shows, for instance, that the 2021 market size of global Finance and Accounting business services will grow up to $\$ 30.4 b n$, while the compound annual growth rate (CAGR) for F\&A business services is $6 \%$ (HfS: F\&A market size and forecast 2017-2021).

From an academic perspective, the review of Holmlund et al. (2016) of business and management literature related to service orientation underpins the call for more research on business service implementation and usage contexts. The authors argue that management, leadership and decision-making in organizations that rely on business services and which are engaged in the transition toward service-based approaches face many challenges for managers that researchers could tap into (p. 2460). In a similar vein, Buhl and Weinhardt (2009) argue that we have to advance service-orientation research internationally and as such contribute to organizations' business models to perform flexibly and smoothly.

Literature, as will be discussed in more detail, shows that service orientation and internal business services have been extensively researched, specifically by making use of literature reviews, case studies and quantitative research (see Table 1). However, few studies in the field of business services studied, based on quantitative empirical data, (1) what type of determinants, such as transparency of business process, maturity of an organization, level of knowledge sharing or use of information systems, are relevant in relation to an organization's service-oriented strategy and subsequently (2) to what degree they affect the implementation of such a service-oriented strategy. We define a service-oriented strategy as the deliberate choice of a firm to base their business strategy on clear choices with regard to how business services are internally addressed and enabled within the organization. Consequently, if organizations are unaware of influencing determinants, this may result in management decisions that lead to barriers that affect the implementation of a service-oriented strategy. We argue that a theory-based research is required to identify and analyze how and to what degree key determinants explain an organization's service-oriented strategy. Therefore, the leading research question in this paper is:

$R Q 1$. How and to what degree do the key determinants that can be influenced by organizations' management affect a service-oriented strategy with a focus on organization's business services?

In this paper, we aim to address this research question by proposing and validating a conceptual model explaining the service orientation of an organization and by examining the 


\begin{tabular}{|c|c|c|c|c|}
\hline Constructs & Source & Type of Research & Key attributes & \\
\hline \multirow[t]{9}{*}{$\begin{array}{l}\text { Service } \\
\text { orientation }\end{array}$} & $\begin{array}{l}\text { Homburg et al. } \\
(2002)\end{array}$ & Empirical research & Business strategy, Performance outcomes & orientation \\
\hline & $\begin{array}{l}\text { Czarnitzki and } \\
\text { Spielkamp (2003) }\end{array}$ & Literature review & $\begin{array}{l}\text { Business services, Innovation, } \\
\text { Knowledge }\end{array}$ & \\
\hline & $\begin{array}{l}\text { Lytle and } \\
\text { Timmerman (2006) }\end{array}$ & $\begin{array}{l}\text { Empirical research } \\
\text { (quantitative method) }\end{array}$ & $\begin{array}{l}\text { Organizational performance, Employee } \\
\text { commitment, Product performance }\end{array}$ & 3 \\
\hline & Yoon et al. (2007) & $\begin{array}{l}\text { Empirical research } \\
\text { (quantitative method) }\end{array}$ & $\begin{array}{l}\text { Business performance, Service value, } \\
\text { Employee satisfaction }\end{array}$ & \\
\hline & $\begin{array}{l}\text { Janssen and Joha } \\
(2008)\end{array}$ & $\begin{array}{l}\text { Literature review, case } \\
\text { study }\end{array}$ & $\begin{array}{l}\text { Strategy, Organizational redesign, } \\
\text { Processes, Transformation }\end{array}$ & \\
\hline & $\begin{array}{l}\text { Teng and Barrows, } \\
2009\end{array}$ & Literature review & Employee, Management and organization & \\
\hline & Murray et al. (2009) & Literature review & $\begin{array}{l}\text { Sourcing strategy, Knowledge, } \\
\text { Capabilities, Performance }\end{array}$ & \\
\hline & Gebauer et al. (2010) & $\begin{array}{l}\text { Empirical research } \\
\text { (quantitative method) }\end{array}$ & $\begin{array}{l}\text { Service strategies, Organizational } \\
\text { designs, Performance }\end{array}$ & \\
\hline & Aier et al. (2011) & $\begin{array}{l}\text { Empirical research } \\
\text { (quantitative method) }\end{array}$ & $\begin{array}{l}\text { Service strategy, Organization and } \\
\text { culture, Communication, Projects, } \\
\text { Success }\end{array}$ & \\
\hline \multirow[t]{9}{*}{$\begin{array}{l}\text { Business } \\
\text { services }\end{array}$} & $\begin{array}{l}\text { Esteves and Pastor } \\
(2001)\end{array}$ & Literature review & $\begin{array}{l}\text { Information Systems, Life cycle, Business } \\
\text { processes }\end{array}$ & \\
\hline & $\begin{array}{l}\text { Fremantle et al. } \\
(2002)\end{array}$ & Literature review & $\begin{array}{l}\text { Web services, Information systems, } \\
\text { Integration }\end{array}$ & \\
\hline & $\begin{array}{l}\text { Cherbakov et al. } \\
\text { (2005) }\end{array}$ & $\begin{array}{l}\text { Literature review, case } \\
\text { study }\end{array}$ & $\begin{array}{l}\text { Componentization, Value net, Information } \\
\text { systems }\end{array}$ & \\
\hline & Schroth (2007) & Literature review & Web services, Information systems & \\
\hline & $\begin{array}{l}\text { Demirkan et al. } \\
\text { (2008) }\end{array}$ & Literature review & $\begin{array}{l}\text { Customer perspective, Economics, } \\
\text { Information Technology strategy }\end{array}$ & \\
\hline & $\begin{array}{l}\text { Van Van der Aalst } \\
(2012)\end{array}$ & Literature review & $\begin{array}{l}\text { Business processes, Process-aware } \\
\text { information systems }\end{array}$ & \\
\hline & Wynstra et al. (2015) & Literature review & $\begin{array}{l}\text { Governance, Capabilities, Contracting, } \\
\text { Management }\end{array}$ & \\
\hline & Alreemy et al., (2016) & Literature review & $\begin{array}{l}\text { Information Systems, Governance, } \\
\text { Success factors }\end{array}$ & $\begin{array}{r}\text { Table } 1 . \\
\text { Overview of service- }\end{array}$ \\
\hline & $\begin{array}{l}\text { Holmlund et al. } \\
\text { (2016) }\end{array}$ & Literature review & $\begin{array}{l}\text { Financial issues, Management, Decision- } \\
\text { making }\end{array}$ & $\begin{array}{l}\text { oriented and business } \\
\text { services research }\end{array}$ \\
\hline
\end{tabular}

relationship between various determinants and the organization's service-orientation strategy. This paper is organized as follow. First, our theoretical background addresses the concepts of service orientation and business services. Based on these insights, a research model is proposed, and we develop research hypotheses. The research methodology is presented in Section 3, and next, the data analysis and results are addressed in Section 4. Discussions and the conclusion are presented in Section 5 and 6, respectively.

\section{Theoretical background}

We identify determinants of a service-oriented strategy by conducting a systematic literature review in an open way and not based on predefined expectations on which concepts to study in order to explain a service-oriented strategy. Publications on the concepts of service orientation and business services, both from a technical, that is, information systems and an organizational perspective, were identified through searches making use of three search engines, namely: Scopus, Web of Science and Google Scholar selecting publications from 2000 
BPMJ 27,8

to 2018. Search terms that were used, either separately or in combination, include service orientation, business services, organization, strategy, management, transition, implementation and determinants. Publications include a broad variety of academic publications, such as: Journal of Business Research, Information and Organization, Journal of Services Marketing, Journal of Services Management, Communications of the ACM, Digital Information Management, Business Process Management Journal and Journal of Operations Management. The selection was based on two criteria. First, publications were selected that include at least one search term in the title, abstract or keywords. Second, to ensure reliability of the data collection, only reviewed journals, book chapters and conference proceedings with more than 50 citations were selected. In order to look for recent insights we also searched for relevant conference papers, where the citation criteria were less relevant, but contained new proposed perspectives as derived from the abstract.

As we aim at assessing business services from an organizational perspective, we excluded computing and modeling views.

Based on analysis of selected key publications, we find five generally considered determinants of which three correspond to both a service-orientation strategy and business services, namely business processes, governance, process-aware information systems. Two determinants correspond to a service-orientation strategy specifically, organizational readiness and knowledge sharing. Next, we elaborate on the service orientation and business services concepts and the five determinants in more detail.

\subsection{Service orientation}

Literature on service orientation shows two main perspectives, namely technical and organizational. Cherbakov et al. (2005), for instance, used an information system view to study service orientation and described this concept as a set of cooperating business services that are loosely coupled and supported by applications that span organizations and multiple information systems. Today, organizations invest in business environments that are enabled by technical solutions and, as such, opportunities arise to provide business value in service relationships (Arsanjani, 2002). This results in an emerging service-oriented way of thinking, which leverages technology in a response to cater for changing circumstances (Demirkan et al., 2008). By adopting service orientation, web services are created that are modular, accessible and interoperable (Fremantle $e t$ al., 2002), which allows organizations to redesign business processes by reusing and combining existing (web) services.

We argue that the second perspective on service orientation, for example, an organizational view, is required to study a firm's service-oriented strategy, as business services are enabled within an organization. Service orientation has been conceptualized at the organizational level, where the emphasis is on the extent to which an organization is internally service-oriented (Homburg et al., 2002; Eichengreen and Gupta, 2012). Despite the multitudes of publications on service orientation, the management side of the effects of implementing a service-orientation approach tends to receive less attention. Lytle and Timmerman (2006) define service orientation as "an organization-wide embracement of a basic set of relatively enduring organizational policies, practices, and procedures intended to support and reward service-giving behaviors that create and deliver service excellence (p. 136)." This is in line with our definition of service-oriented strategy as the deliberate choice of an organization to base their business strategy on clear choices with regard to how business services are internally addressed and enabled in an organization.

Organizations that want to focus on service orientation have to deal with change. Organizational readiness helps to decrease the degree of risk associated with the implementation of a service-oriented strategy (Armenakis and Bedeian, 1999). When organizational readiness for change is high, literature shows that organizational members are 
more willing to invest in the change effort, which contributes to a more successful change implementation (Armenakis and Harris, 2002). Importantly, a service-oriented strategy is influenced by the ability and willingness of managers and employees of an organization to share knowledge on a day-to-day basis (Orlikowski, 2002). Applying knowledge sharing may encounter certain challenges, in particular when teams are faced with geographical and timezone differences (Kotlarsky and Oshri, 2005).

\subsection{Business services}

Previous studies show that an organization's service-oriented strategy is influenced by the availability and need for their business services (Murray et al., 2009; Wynstra et al., 2015; Holmlund et al., 2016). Wirtz et al. (2015) argue that business services consist of a variety of services (e.g. legal, accountancy, product and end-user service design, research and development and (information) technology support). To improve effectiveness, organizations decompose their enterprise and corresponding business services into smaller autonomous business components that may interact with other business components. The decomposition of organizations makes complexity manageable and, as such, business services can be integrated and/or disintegrated.

Applying a service-orientation approach, business processes are managed across an organization that requires breaking down siloed business processes into modular independent services (Demirkan et al., 2008) that support dynamic processes. Considering dynamic processes, each subsequent process step may be based on the full or partial results of previous steps. Consequently, dynamic processes increase a firm's organizational responsiveness to cater for market changes. Next, to support business services, process-aware information systems (PAISs) must be loosely coupled to create dynamic business processes (Janssen, 2008) and, therefore, form a prerequisite to enable strategic decision-making. Tightly coupled business services and PAIS, on the other hand, may hinder the degree of service-oriented effectiveness. Due to the evolution of PAIS (e.g. web services, architectures, application, practices) and of corresponding business processes, Alreemy et al. (2016) state that appropriate governance is essential to achieve organizational success.

\subsection{Development of hypotheses}

Our literature review shows three generally considered determinants that correspond to a service-oriented strategy directly. First, the way in which business services are established influences the implementation of an organization's service-oriented strategy. Wirtz et al. (2015) define business services as services that "consist of a variety of knowledge-intensive and creative professional services (e.g., legal, accountancy, market research, consulting, design, and research and development), IT and technology-intensive services" (p. 569). Cherbakov et al. (2005) argue that in order to become more agile, organizations have to focus on their core competences and reorganize business tasks. As such, an enterprise transforms into a collection of autonomous business services that may interact with each other. Organizations may modularize business services into business components to manage complexity (Arsanjani, 2002). In doing so, they are able to integrate and disintegrate existing business components. Consequently, organizations are able to create an internal business ecosystem that consists of a federation of collaborating knowledge-intensive business services. We argue that organizations implement a service-oriented strategy that takes modularized business services into account across functional domains and geographical scope. As such, business services can be managed to respond to rapidly changing business environments. Therefore:

H1. The more business services are integrated, the easier (or more effective) a serviceoriented strategy will be implemented.

Revitalization of service orientation 
BPMJ 27,8

Second, in applying a service-oriented strategy, organizational readiness becomes essential. Literature postulates that to adapt to an organizational change effectively, which corresponds to implementing a service-oriented strategy, organizations have to prepare internally to cater for the change (Armenakis and Bedeian, 1999). Holt et al. (2007) define organizational readiness as "a comprehensive attitude that is influenced simultaneously by the content, the process, the context, and the individuals involved" (p. 235). Organizational readiness is supported by the way in which processes are formalized (Ein-Dor and Segev, 1978), degree of committed top management (Abdolvand et al., 2008) and level of IT readiness (Bassellier and Benbasat, 2004). Organizational readiness relates to an organization's implementation management capability that strives to effectively transition a serviceoriented strategy and corresponding business services (Luo et al., 2012). Therefore:

H2. The higher the organizational readiness, the easier (or more effective) a serviceoriented strategy will be implemented.

Knowledge sharing has become an important component in developing an organization's business strategy (Wang and Hou, 2015; Zhang, 2018). Lee (2001) defines knowledge sharing "as activities of transferring or disseminating knowledge from one person, group or organization to another" (p. 324). Importantly, the way how knowledge can be shared is considered to be a major management issue as knowledge includes both tacit and explicit knowledge. Implementing a service-oriented strategy is complex and inherently incomplete because organizations have to deal with uncertainty. As such, knowledge sharing can be seen as a mechanism to overcome uncertainty. Hence, organizations should invest in building knowledge sharing mechanisms to support the exchange of information (Rai et al., 2012). Therefore:

H3. The more knowledge is being shared, the easier (or more effective) a service-oriented strategy will be implemented.

Based on our literature review we find three determinants that correspond to both a service-oriented strategy and business services. In an effort to adapt to changing circumstances, organizations deconstruct their business processes into modular independent services that makes it easier to focus on their core capabilities (Bharadwaj et al., 2013; Demirkan et al., 2008). Baldwin and Clark (1997) define modularization as a strategy for organizing complex products and processes efficiently. A modular system is composed of modules that are designed independently but still function as an integrated whole (p. 86), making use of a common architecture. Modularization requires a dynamic orchestration of business processes that is in contrast with processes that are designed from a predefined static sequence, in which process steps must be completed before starting a new process. According to Van der Aalst (2012), the choreography of services is essential to create business process flexibility and, as such, modularized business services that can be managed in various configurations are a precondition. We argue that organizations that have modularized business processes, and reassess these modularized processes on a regular basis, can implement a service oriented strategy more effectively. Therefore:

H4. If business processes are modularized, then an organization's service-oriented strategy will be implemented more effectively.

H4a. Modularized business processes positively influence integrated business services.

However, these hypotheses assume all business services as being equal, as such, the functional scale and geographical scope might mediate this relation; therefore, we posit the next more detailed hypothesis. 
H4b. The relationship between modularized business processes and implementation of a service-oriented strategy is mediated by the nature of business services.

Alreemy et al. (2016) argue that governance supports business services by means of providing clear organizational guidelines in addressing who (organizational department or team) is responsible for managing these services. Aier et al. (2011) define service-orientation governance as "the organizational responsibilities for managing the service landscape" (p. 93). Since service orientation fundamentally breaks with traditional fragmented or monolithic systems in supporting business services, Weill and Ross (2004) argue that organizations have to promote a culture of willingness to embrace such a change. Bieberstein et al. (2005) state that senior management is in the position to encourage willingness and enforce strict governance of service-orientation practices. Therefore, existing intensive governance practices need to be in place in order to enable an organization to apply business services effectively over functional domains and geographical areas. Therefore:

H5. If governance is more strictly applied, then an organization's service-oriented strategy will be implemented more effectively.

$H 5 a$. If governance is more strictly applied, the better business services are integrated.

H5b. The relationship between governance and implementation of a service-oriented strategy is mediated by an organization's integrated business services.

As the scope of enterprises has grown dramatically, business services are often supported by different business processes that are increasingly integrated with each other. This implies that PAISs are interconnected as applications increasingly need to work together (Izza, 2009; Van der Aalst et al., 2007). Van der Aalst defines PAIS as a system that "support the operations of an organization based on models of both the organization and the processes involved" (2007, p 6). Originally, to support their business processes, organizations often used customized software. To cater for changing circumstances rapidly, organizations focused on standardization to create agility. Consequently, more generic software was developed, such as Workflow Management (WFM) systems, Business Process Management (BPM) systems and Enterprise Resource Planning (ERP) systems. In practice, PAIS supports business processes such as finance and accounting, procurement and Human Resource (HR). As such, PAIS provides flexibility to support business processes and the adaptation of modular business services (Fremantle et al., 2002). To support modular business services, PAIS must be interoperable to reuse existing services and assemble them into new business services, which is key to enterprise integration. Consequently, by applying interoperability principle over different functionalities and geographical areas, enterprises are able to decrease the degree of business services complexity. In doing so, business services can be more easily adjusted to respond to endogenous developments (Overby et al., 2006). Therefore:

H6. The more PAISs are interoperable, the more effective a service-oriented strategy will be.

H6a. The more PAISs are interoperable, the better business services are integrated.

H6b. The relationship between PAISs interoperability and implementation of a serviceoriented strategy is mediated by an organization's integrated business services.

Figure 1 shows the research proposed conceptual model and summarizes the path relationships. The theoretical model posits that service-oriented strategy is affected directly by business processes, governance and PAIS, but can be mediated by the domain of the business services as well. Furthermore, we propose that organizational readiness and knowledge sharing positively influence an organization's service-oriented strategy.
Revitalization of service orientation 


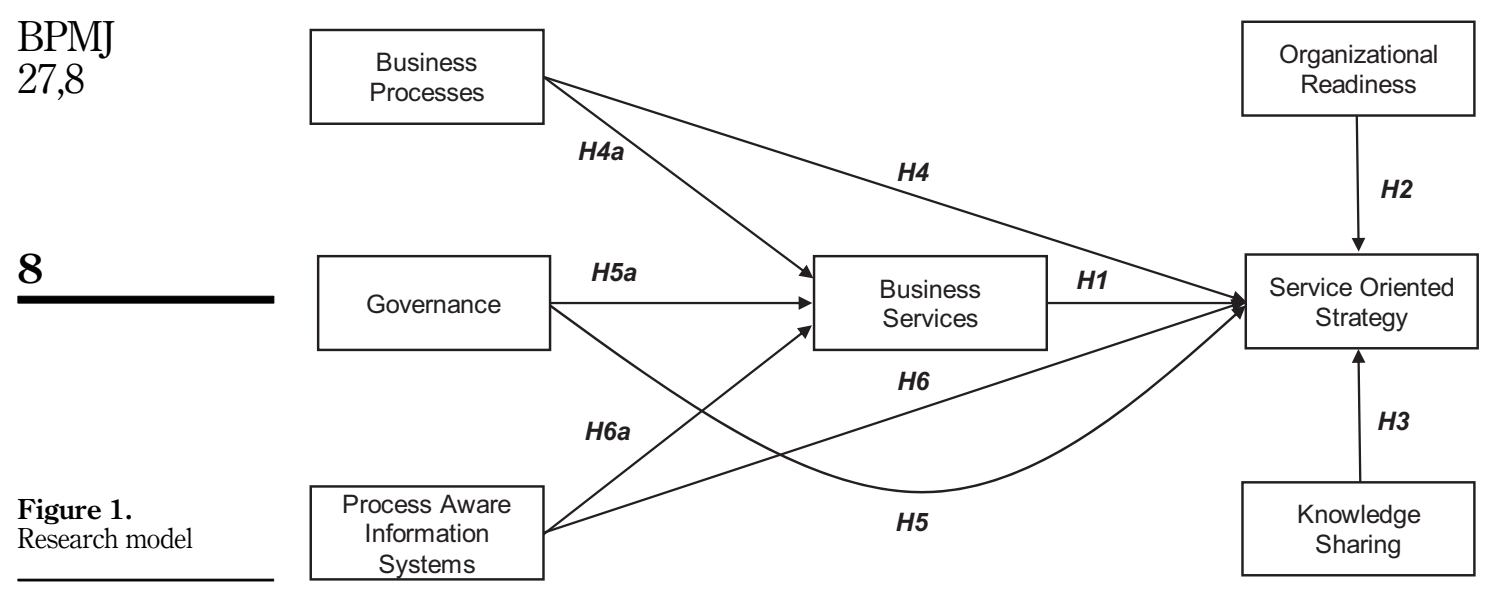

\section{Research methodology}

To find and identify the relationships among the constructs, the data set was analyzed using structural equation modeling (SEM) techniques through partial least squares (PLS), which focuses on the analysis of variance (Hair et al., 2011, p. 139; Hair et al., 2016), using SmartPLS (Ringle et al., 2005). PLS-SEM is an appropriate approach when situations are encountered, like sample size is small and predictive accuracy (Wong, 2011). Because our study is based on a rather small sample size and the predictive accuracy is paramount, we used PLS.

\subsection{Measurement model}

To ensure the reliability of the measurement and to have a comprehensive list of measures, we performed an extensive literature review. We selected all survey items for each construct from previously validated measures. When necessary, minor modifications were made (items reworded) to fit the specific context of the research. In total 31 items were included in the final analysis, see Table A1. Literature revealed that three main criteria influence a serviceoriented strategy: (1) the degree of maturity (Welke et al., 2011), (2) the size of a firm (Aier et al., 2011) and (3) geography (Ciarli et al., 2012). Therefore, we included the size of the global organizations (small $=<10,000$ and large $>10,000$ employees) and location of the firm ( 1 = North and South America, 2 = Europe and Asia Pacific and Africa) in our study as control variables to further investigate if the path relationships are affected by the size and the locations of the organizations.

\subsection{Sample and data collection}

As our population exists of organizations that implemented a service-oriented strategy, we used those three criteria mentioned earlier to select appropriate organizations. This decision is justified in the following manners. First, organizations that have some degree of experience in managing business services are more likely to implement a service-oriented strategy. Second, we may assume that the size of an organization has an effect on the degree in which a service-oriented strategy is implemented. We assume that organizations have to have a certain volume, as indicated by the number of employees to make an effective serviceoriented strategy relevant (the bottom line is $500 \mathrm{ft}$ ). Relatively small organizations (i.e. less than or equal to 10,000 ft) are expected to experience less difficulties to implement a serviceoriented strategy compared to large organizations (more than 100,000 ft) that have to take multiple departments and stakeholders into account. Third, the geographical location in 
which an organization operates may influence the complexity to implement a service-oriented strategy due to differences in intrafirm relationships.

To select appropriate organizations, first, we selected organizations with an experience of minimum three years in establishing a service-oriented strategy. Second, we selected global organizations with sizes in two categories, namely: small organizations $(=<10.000 \mathrm{ft})$ and large organizations $(>10.000 \mathrm{ft}$ ), in a wide variety of industries (see Table A2) in both the profit and nonprofit domains. Third, we selected organizations from five (5) different geographies (e.g. North and South America, Europe, Asia Pacific and Africa), spanning 21 countries. For the final data collection, two respondent profiles were defined. Only participants that matched these profiles were asked to complete the survey. The first profile dealt with the managers, for example, director, vice president - at an executive level who were actively involved in implementing and managing business services organizations. The second profile dealt with the senior managers who were involved in managing shared service centers and retained organizations. We have selected data from organizations in ten different industries that satisfy all of these criteria and that were willing to participate. We collected data on organizations' strategic business directions as implemented in a service-oriented strategy. As confidential and sensitive information is concerned, we anonymized the organizations. All organizations had been engaged in implementing a service-oriented strategy.

To answer our research question "how and to what degree do the key determinants that can be influenced by organizations' management, affect a service-oriented strategy with a focus on organization's business services?" we collected data based on a paper-based questionnaire, administered in face-to-face meetings, which addresses seven constructs. It came with a short cover letter that explained the purpose of the study. The questionnaire was developed in English and was refined during a pretest to improve the clarity of the questions and completed by 15 respondents that represented both scientists and practitioners. We distributed 267 invitations in total and the final sample contained 131 useable responses for the further analysis (response rate 49\%). Analysis of the nonresponsiveness shows three explanations. The first group of participants responded that they are associated with another target group than defined in our survey. The second group of participants refused to fill out the survey as they were not primarily involved in implementing a service-oriented strategy. The third group of respondents indicated that they had insufficient time. As the data was collected on a global level during face-to-face meetings, the rich data set is quite unique, representing a population of internationally operating organizations in diverse industries. An overview of the number of selected organizations per industry and industry details is shown in Table A2.

\section{Data analysis and results}

Consistent with prior research, we analyzed the research model in two stages (Gefen and Straub, 2005): (1) measurement model assessment and (2) structural model assessment. All of the indicators are reflective as they are highly correlated and interchangeable. To assess the reliability and validity, the outer loadings, composite reliability, average variance extracted (AVE) and its square root should be examined (Hair et al., 2012). Hulland (1999) argued that the values of outer loadings should be 0.70 , in this paper all indicators, expect for one item (BusSer_3), were loaded significantly on their respective constructs with primary loadings more than 0.70 , see Table 2. Moreover, it is important to establish the reliability and validity of the latent variables to ensure that the collected data fits the research model.

\subsection{Validity and reliability}

Since we measure variables on self-reported data with regard to both the dependent variable and independent variables, common method bias (CMB) is a potential issue
Revitalization of service orientation 


\begin{tabular}{|c|c|c|c|c|c|c|c|c|c|}
\hline \multirow{2}{*}{$\begin{array}{l}\text { BPMJ } \\
27,8\end{array}$} & \\
\hline & Construct & Items & $\begin{array}{c}\text { Factor } \\
\text { loadings }\end{array}$ & Mean & $\begin{array}{l}\text { Std. } \\
\text { dev }\end{array}$ & $t$-statistic & $\alpha$ & $\mathrm{CR}^{\mathrm{b}}$ & $\mathrm{AVE}^{\mathrm{a}}$ \\
\hline \multirow{6}{*}{10} & \multirow[t]{5}{*}{ SO strategy } & SOS_1 & 0.701 & 3.11 & 0.97 & 10.220 & \multirow[t]{5}{*}{0.812} & \multirow[t]{5}{*}{0.869} & \multirow[t]{5}{*}{0.572} \\
\hline & & SOS_2 & 0.780 & 2.73 & 0.82 & 6.540 & & & \\
\hline & & SOS_3 & 0.814 & 3.18 & 0.79 & 25.139 & & & \\
\hline & & SOS_4 & 0.799 & 3.23 & 0.89 & 12.131 & & & \\
\hline & & SOS_5 & 0.732 & 3.45 & 1.02 & 15.195 & & & \\
\hline & \multirow{4}{*}{$\begin{array}{l}\text { Organizational } \\
\text { readiness }\end{array}$} & OrgRead_1 & 0.878 & 4.93 & 1.18 & 4.395 & \multirow[t]{4}{*}{0.877} & \multirow[t]{4}{*}{0.915} & \multirow[t]{4}{*}{0.730} \\
\hline & & OrgRead_2 & 0.861 & 3.82 & 1.13 & 4.526 & & & \\
\hline & & OrgRead_3 & 0.873 & 3.95 & 1.09 & 4.693 & & & \\
\hline & & OrgRead_4 & 0.8 .03 & 4.11 & 0.99 & 4.661 & & & \\
\hline & \multirow[t]{7}{*}{ Knowledge sharing } & KSH_1 & 0.698 & 2.46 & 0.81 & 6.423 & \multirow[t]{7}{*}{0.835} & \multirow[t]{7}{*}{0.877} & \multirow[t]{7}{*}{0.505} \\
\hline & & KSH_2 & 0.729 & 2.59 & 0.77 & 4.710 & & & \\
\hline & & KSH_3 & 0.717 & 3.51 & 0.99 & 14.722 & & & \\
\hline & & KSH_4 & 0.742 & 2.98 & 1.21 & 13.710 & & & \\
\hline & & KSH_5 & 0.743 & 3.11 & 0.98 & 12.982 & & & \\
\hline & & KSH_6 & 0.761 & 3.02 & 0.87 & 21.730 & & & \\
\hline & & KSH_7 & 0.719 & 2.89 & 0.91 & 18.757 & & & \\
\hline & \multirow[t]{2}{*}{ Business services } & BusSer_1 & 0.812 & 3.48 & 1.04 & 18.402 & \multirow[t]{2}{*}{0.712} & \multirow[t]{2}{*}{0.755} & \multirow[t]{2}{*}{0.633} \\
\hline & & BusSer_2 & 0.892 & 3.39 & 1.08 & 34.810 & & & \\
\hline & \multirow[t]{6}{*}{ Business processes } & BusPro_1 & 0.807 & 2.66 & 0.99 & 12.240 & \multirow[t]{6}{*}{0.802} & \multirow[t]{6}{*}{0.857} & \multirow[t]{6}{*}{0.612} \\
\hline & & BusPro_2 & 0.722 & 2.79 & 1.05 & 10.503 & & & \\
\hline & & BusPro_3 & 0.775 & 2.49 & 1.01 & 22.374 & & & \\
\hline & & BusPro_4 & 0.709 & 2.62 & 1.66 & 12.661 & & & \\
\hline & & BusPro_5 & 0.776 & 2.33 & 1.07 & 22.791 & & & \\
\hline & & BusPro_6 & 0.925 & 3.03 & 1.04 & 12.608 & & & \\
\hline & \multirow[t]{4}{*}{ Governance } & Govern_1 & 0.768 & 2.97 & 1.29 & 40.199 & \multirow[t]{4}{*}{0.734} & \multirow[t]{4}{*}{0.833} & \multirow[t]{4}{*}{0.555} \\
\hline & & Govern_2 & 0.765 & 2.83 & 0.86 & 22.215 & & & \\
\hline & & Govern_3 & 0.753 & 2.97 & 0.98 & 17.343 & & & \\
\hline Table 2. & & Govern_4 & 0.699 & 3.23 & 1.11 & 19.033 & & & \\
\hline Descriptive statistics, & \multirow[t]{3}{*}{ PAIS } & IS_1 & 0.700 & 2.72 & 0.63 & 3.005 & 0.732 & 0.762 & 0.621 \\
\hline internal consistency & & IS_2 & 0.933 & 2.58 & 1.08 & 8.361 & & & \\
\hline and reliability of items & & IS_3 & 0.705 & 2.31 & 1.18 & 3.204 & & & \\
\hline
\end{tabular}

(Podsakoff et al., 2003). To assess whether a CMB is a problem, two different approaches were used to test CMB issues. In the first approach, the Harman's single-factor test (Podsakoff et al., 2003) resulted in seven factors explaining $69.37 \%$ of the variance. The test results show no single factor with a significant $(\phi<0.05)$ loading for all items. We added an unmeasured latent method factor and all items were loaded on both their theoretical constructs and the method factor and show an adequate model fit (Bagozzi and Yi, 1988). All item loadings on the common method factor were much lower than the loadings on their respective constructs. Moreover, we found that there were no qualitatively differences for all path coefficients after introducing the method factor. Thus, we concluded that $\mathrm{CMB}$ is not likely to be an issue. Second, we used the common latent factor (CLF) that is a preferred approach over Harman's one-factor test (MacKenzie and Podsakoff, 2012). We use the Chi-square difference test between the unconstrained model and a model where all of the paths are constrained to zero. The CLF test did not show any paths affected by the CMB. As we use reflective measures, we do not need to assess the multicollinearity.

Moreover, after assessing the path coefficient for the inner model, we assess the outer model by examining the $t$-statistics values. As shown in Table 2 , all of the $t$-statistics values are higher than 1.96. Thus, we can conclude that the outer model loadings are highly significant. Although Cronbach's alpha $(\alpha)$ tends to provide a conservative measurement in 
PLS-SEM, it is often used to measure internal consistency reliability. To address this issue, some researchers (Bagozzi and Yi, 1988; Hair et al., 2012) have recommended to use the composite reliability (CR) as a replacement, which should be 0.70 . Table 2 shows high levels of internal consistency and reliability and demonstrates the Cronbach alpha values and $\mathrm{CR}$ values among all seven reflective latent variables, with a lowest value of 0.755 for $\mathrm{CR}$ and 0.712 for Cronbach's alpha $(\alpha)$. For convergent validity, the AVE for each latent variable was examined and recommended value is 0.50 or higher (Bagozzi and Yi, 1988). Table 2 shows that all of the AVE values are greater (the lowest value is 0.555 ) than the acceptable threshold, so we can conclude that the convergent validity is confirmed.

Discriminant validity guarantees the uniqueness of a measuring construct and indicates that the phenomenon of interest is not captured in other latent variables within the research model (Henseler et al., 2015). Fornell and Larcker (1981) suggest using the square root of AVE in each latent variable to examine and establish discriminant validity and stated the value should be higher than other correlation values among the latent variables. To do so, the square root of AVE is calculated and written in bold on the diagonal in Table 3.

This paper, in addition to the Fornell-Larcker criterion and the assessment of crossloadings, employs a second test for the discriminant validity, that is, the heterotraitmonotrait ratio of correlations (HTMT). HTMT is an alternative to the conventional (Fornell-Larcker) assessment for reliably detecting the lack of discriminant validity. Some researchers, such as Rönkkö and Evermann (2013) and Henseler et al. (2015), demonstrated that the Fornell-Larcker criterion and the assessment of the cross-loadings are insufficiently sensitive to detect discriminant validity problems and perform poorly in PLS. HTMT as a criterion, which involves comparing it to a predefined threshold levels 0.85 (Kline, 2011) or 0.90 (Teo et al., 2008), can be used to assess discriminant validity. Table 4 shows that the constructs are clearly unrelated, complying with the HTMT criterion of 0.85 , since all correlations are below this threshold.

\subsection{Structural model analysis}

To test the hypotheses and examine the strength and the significance of relationships between constructs in the proposed research model, we employed SEM. SmartPLS can generate $t$-statistics for significance testing of both the inner and outer model by making use of a bootstrapping, which results in an approximation of the normality of data. We took a large number of subsamples (5.000) from the original sample with replacement to give bootstrap standard errors. This procedure, in turn, provides approximate $t$-values for

\begin{tabular}{|c|c|c|c|c|c|c|c|}
\hline Construct & $\begin{array}{l}\text { Business } \\
\text { services }\end{array}$ & PAIS & Governance & $\begin{array}{l}\text { Knowledge } \\
\text { sharing }\end{array}$ & $\begin{array}{l}\text { Org. } \\
\text { readiness }\end{array}$ & $\begin{array}{l}\text { Business } \\
\text { processes }\end{array}$ & $\begin{array}{c}\text { SO } \\
\text { strategy }\end{array}$ \\
\hline $\begin{array}{l}\text { Business } \\
\text { services }\end{array}$ & 0.708 & & & & & & \\
\hline PAIS & 0.345 & 0.796 & & & & & \\
\hline Governance & 0.557 & 0.298 & 0.722 & & & & \\
\hline $\begin{array}{l}\text { Knowledge } \\
\text { sharing }\end{array}$ & 0.537 & 0.327 & 0.461 & 0.710 & & & \\
\hline $\begin{array}{l}\text { Organizational } \\
\text { readiness }\end{array}$ & 0.364 & 0.407 & 0.312 & 0.435 & 0.854 & & \\
\hline $\begin{array}{l}\text { Business } \\
\text { processes }\end{array}$ & 0.617 & 0.433 & 0.513 & 0.549 & 0.514 & 0.756 & \\
\hline SO strategy & 0.626 & 0.362 & 0.462 & 0.642 & 0.438 & 0.658 & 0.745 \\
\hline
\end{tabular}

Note(s): The square root of AVE is calculated and written in bold on the diagonal

\section{Revitalization of service orientation}


BPMJ

27,8

\section{2}

Table 4.

Heterotrait-monotrait ratio (HTMT) results (implementation of service-oriented strategy) significance testing of the structural path. Using a two-tailed $t$-test with a significance level of $5 \%$, the path coefficient will be significant if the $t$-statistics is larger than 1.96 . We tested the structural model and the PLS path modeling estimation (see Figure 2). The explained variance is $\left(R^{2}=0.56\right)$ for the service-oriented strategy. This means that the three latent variables (organizational readiness, knowledge sharing and business services) explain nearly $56 \%$ of the variance in service-oriented strategy. Moreover, business processes, governance and PAISs together explained $52 \%$ of the variance of business services.

The PLS-SEM analysis shows that the path relationship between business services and service-oriented strategy is significant $(\beta=0.20, t=1.995, p<0.05)$, which supports H1. The path relationship between organizational readiness and service-oriented strategy is not significant, rejecting $\mathrm{H} 2$. The path relationship between knowledge sharing and serviceoriented strategy is significant $(\beta=0.21, t=1.998, p<0.05)$. Therefore, $\mathrm{H} 3$ is also supported by the model.

The SEM results also show that business processes significantly affect the serviceoriented strategy $(\beta=0.65, t=6.964, p<0.001)$, followed by the effect of business processes on business services $(\beta=0.45, t=5.131, p<0.001)$, confirming that H4 and H4a are both supported by the model. The SEM results show that governance has no significant direct

\begin{tabular}{|c|c|c|c|c|c|c|c|}
\hline Construct & $\begin{array}{l}\text { Business } \\
\text { services }\end{array}$ & PAIS & Governance & $\begin{array}{l}\text { Knowledge } \\
\text { sharing }\end{array}$ & $\begin{array}{c}\text { Org. } \\
\text { readiness }\end{array}$ & $\begin{array}{l}\text { Business } \\
\text { processes }\end{array}$ & $\begin{array}{c}\text { SO } \\
\text { strategy }\end{array}$ \\
\hline
\end{tabular}

Business

services

PAIS $\quad 0.569$

Governance $\quad 0.819 \quad 0.536$

$\begin{array}{llll}\text { Knowledge } & 0.647 & 0.551 & 0.667\end{array}$

sharing

$\begin{array}{lllll}\text { Organizational } & 0.424 & 0.658 & 0.422 & 0.532\end{array}$

readiness

Business

processes

SO strategy
0.650

0.817
0.593

$0.534 \quad 0.861$
Figure 2.

Conceptual model results

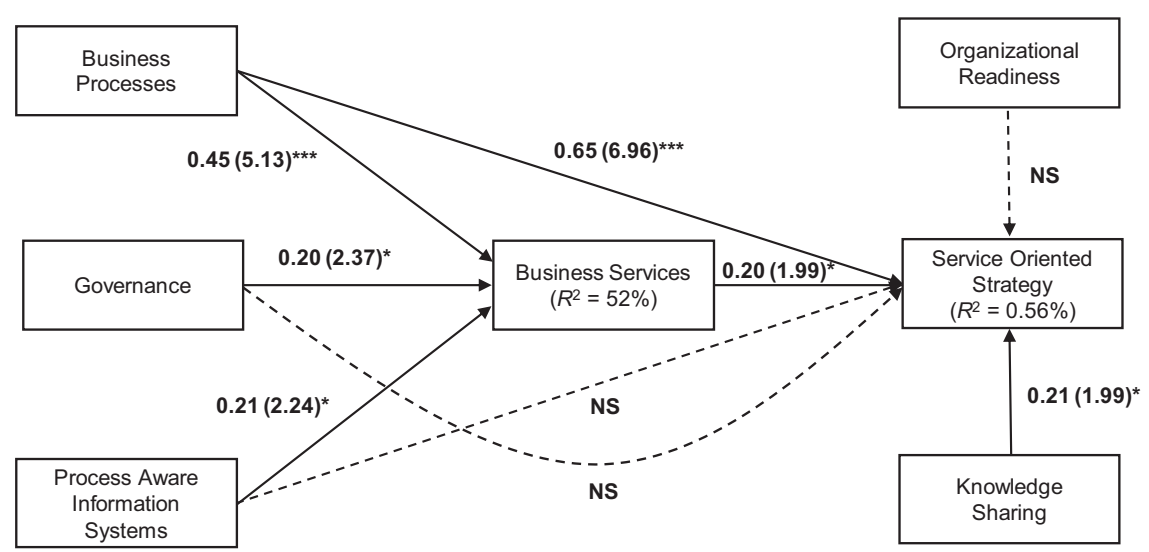

Note(s): ${ }^{*} p$-value $<0.05 ; * * p$-value $<0.01 ; * * * p$-value $<0.001$ 
relationship with service-oriented strategy, thus H5 is not confirmed by the model, but the relationship between governance and business services $(\beta=0.20, t=2.372, p<0.5)$ is significant, which supports H5a. Finally, the SEM analysis shows that the relationship between PAIS and service-oriented strategy is not significant and, therefore, $\mathrm{H} 6$ is rejected. However, there is a significant relationship between PAIS and business services $\beta=0.21$, $t=2.241, p<0.05$ ), thus H6a is supported. We may conclude that business services, business processes and knowledge sharing are strong predictors of a service-oriented strategy.
Revitalization of service orientation

\subsection{Mediation effect}

With regard to the mediating role of business services between three independent variables (i.e. business processes, governance and PAIS to service-oriented strategy), the following observations were noted. As we found no total indirect effect between business processes, governance and PAIS and service-oriented strategy, the mediation test results show that business services fully mediate these path relationships. The specific indirect effect value between business processes $\rightarrow$ business services $\rightarrow$ service-oriented strategy is $(\beta=0.18$, $t=1.981, p<0.05)$. Thus, H4b is supported. The specific indirect effect value between governance $\rightarrow$ business services $\rightarrow$ service-oriented strategy is $(\beta=0.14, t=2.323, p<0.05)$ and for PAIS $\rightarrow$ business services $\rightarrow$ service-oriented strategy is $(\beta=0.11, t=3.112, p<0.01)$. In other words, both H5a and H6a are supported by the model.

\subsection{Moderation effect}

When using organizations' size [small $=<10,000$ and large $>10,000$ ] and geographies [group $1=$ North and South America, group 2 = Europe, Asia Pacific and Africa] as control variables, our analysis revealed some more interesting insights. For large organizations, which are located in Europe, Asia Pacific and Africa, the path between governance and business services is not significant. In contrast, this path is significant for small organizations $(\beta=0.26, t=2.34, p<0.05)$ that are located in North and South America $(\beta=0.23, t=2.04$, $p<0.05)$. It is also found that the path between PAIS and business services is only significant for large organizations located $(\beta=0.30, t=2.26, p<0.01)$ in Europe, Asia Pacific and Africa $(\beta=0.33, t=1.98, p<0.05)$.

The moderation test results also show that for organizations located in the Europe, Asia Pacific and Africa, the path between business processes and business services is not significant, but it is significant for other groups. Interestingly, we found that the path between governance and service-oriented strategy is only significant for organizations located in Europe, Asia Pacific and Africa $(\beta=0.31, t=2.86, p<0.001)$. This path is not significant for the other groups. Moreover, the SEM analysis shows that excluding control variables does not change the relationship, as this path is still not significant. This is consistent with the rejection of H2. The results of the moderating effects are shown in Table 5. The data reveals that size and geography of the organizations have moderating effects on some of the relationships studied.

\section{Discussion}

The findings of this study demonstrate that, based on their direct relationships, business services, business processes and knowledge sharing are perceived to be critical determinants in implementing an organization's service-oriented strategy. Importantly, when business services are adapted due to changing business needs, business processes have to be adjusted too. Vice versa, as a result of the degree of intertwined business processes and business services (Cherbakov et al., 2005), the latter has to be adapted too. So an organizational view is utmost important and the decomposition of enterprises with a focus on internal services and 
BPMJ
27,8

14

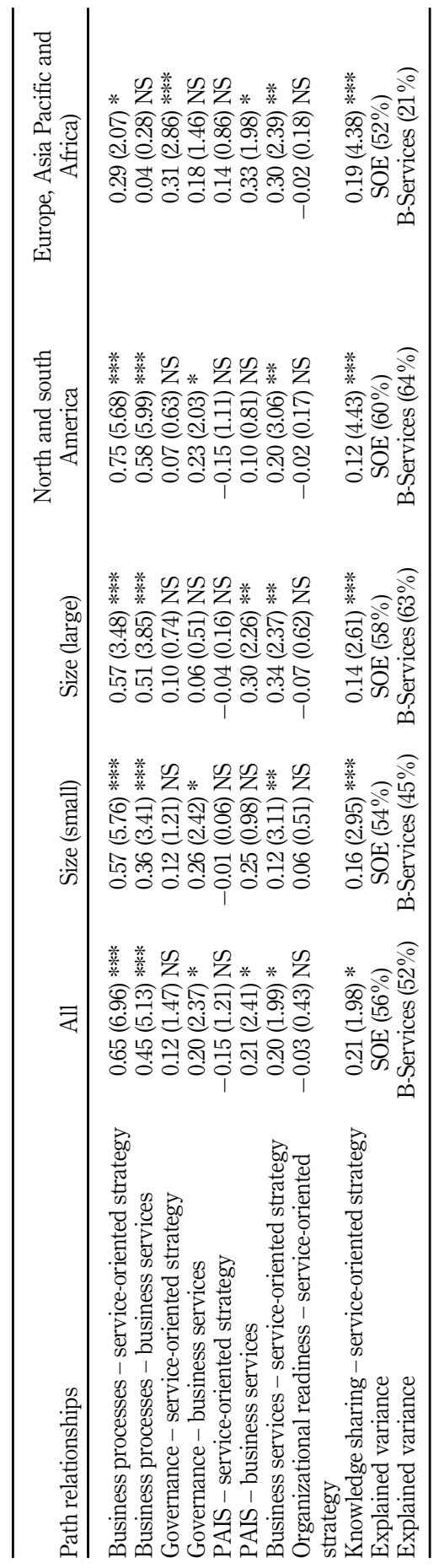

Table 5.

Multigroup analysis results 
service delivery is core, as was already argued by Menor and Roth (2007) and Versteeg and Bouwman (2006) a decade ago. A clear management strategy on the decomposition of the enterprise to reduce complexity needs attention, as well as the process to facilitate such a change. Next, organizations have to possess the necessary knowledge sharing mechanisms to support business services and business processes (Van Van der Aalst, 2012) in order to be able to implement a service-oriented strategy.

Moreover, we did not find evidence that governance and PAIS directly affect a serviceoriented strategy. An explanation may be found in the research of Aier et al. (2011) in which governance and architecture and service design are perceived as indirect factors that influence service-oriented project success. This finding is confirmed in our research, as we found that business services functionality scale and scope fully mediate the relationships between business processes, governance and PAIS to a service-oriented strategy. Our research did not find a direct relationship between organizational readiness and a serviceoriented strategy, which is in contrast with the research conducted by Verdú and Gómez-Gras (2009). These authors demonstrate that organizations that are most sensitive to the demands of the environment (superior organizational responsiveness) show better results to achieve managerial flexibility. In our study we did not include environmental focus in our research design, as we consider this to be a more strategy-related foci.

Literature on organizational readiness shows that there is no consensus about which dimensions constitute organizational readiness (e.g. size of an organization, type of business process integration, scope of readiness) (Martin et al., 2008). Additional research is necessary to create more insights in the concept of organizational readiness beyond simple maturityfocused approaches (see for instance Becker et al., 2009). Our findings demonstrate that business services, business processes, governance and PAIS are affected by the moderating effect of organizations' size and geographical scale. Karmarkar (2004) argues that business processes have to be closely synchronized with business services and carefully managed, taking the geographical location of services into account. Moreover, we find that the relationship between governance and business services is affected by the geographical location of an organization. Ojala and Tyrväinen (2007) find that small organizations that use business services favor a low geographical distance as governance agreements are easier to deal with. With regard to the relationship between PAIS and business services, we find that the organizations' size (small organizations) and the organizations' location (Europe, Asia Pacific and Africa) moderate this relationship. A study of Lacity et al. (2017) on information systems shows that a firm's size does not have an effect on business services and related sourcing outcomes. In this study organizations are rather large $(>10.000 \mathrm{ft})$ and it might be interesting to focus in future research on smaller international operating organizations (from 1.000 up to $10.000 \mathrm{ft}$ ). With regard to geographical scope, Prikladnicki and Audy (2012) find evidence that cultural distance (as implied by geographical differences between continents) is experienced as a major challenge that affects a firm's business performance. Nevertheless, research into the moderating effects of size and specifically geography needs more attention. Clearly there are different patterns between organizations that operate in the Americas and other parts of the world. The degree to which geography affects the research constructs is not clear and requires more research as well as theoretical grounding, beyond the conceptualization of Hofstede (1998).

Our study has important implications for research. Our results partially support the proposed research model and constitute a start for further theory formation. The renewed attention to the concept of service orientation provides insights into critical determinants that influence the implementation of a service-oriented strategy. We argue that in order to cater for changes, organizations have to manage and adapt the coherence of the determinants' business services, business processes and knowledge sharing continuously. Hence, these determinants can be perceived as a firm's dynamic capability. Teece et al. (1997) argued that
Revitalization of service orientation 
BPMJ 27,8

organizations require dynamic resources to manage and organize both content and processes to achieve sustainability. This dynamic capability is needed to implement and sustain a service-oriented approach. Our research also contributes to practitioners and, specifically, organizations' management. In regard to our initial research question, our results suggest that leadership has to manage the interplay between business processes, governance and PAIS to support business services effectively.

On a practical level, we postulate that an organization's executive management should pay attention to invest in an organizational entity (department) that manages business services continuously. This organizational entity has to ensure that related processes and knowledge sharing are in place to establish and maintain a service-oriented strategy.

\section{Conclusion and limitations}

To the best of our knowledge, this paper is the first analysis of determinants that influence the implementation of an organization's service-oriented strategy. Based on related research in the field of business services, within the context of service orientation, we theoretically developed and empirically evaluated and validated a research model. The model is aimed at explaining critical determinants based on unique data. Our research contributes to serviceoriented literature by operationalizing the implementation of an organization's serviceoriented strategy. Our insights go beyond the findings of Aier et al. (2011). The authors found that a service-oriented strategy influences service-oriented project success positively. We extended these findings, based on a unique data set, by studying business services and influencing determinants (i.e. business processes, governance, PAIS and knowledge sharing) within the context of service orientation. We argue that a fit between these key determinants is paramount to achieve and sustain a service-oriented strategy. Consequently, organizations' leadership has to manage the coherence between these determinants and adapt them if necessary. By conducting this study we respond to the call of Holmlund et al. (2016) for more research on management and leadership challenges in business services companies during the transition to service orientation (p. 2460). This study sheds light on the revitalization of the service-orientation concept that is seen as a strategic instrument for organizations' organizational responsiveness. A limitation is imposed by the limited sample size and the unbalanced response of participants (executive management). In future research, a more extensive survey among a broader group of participants will help us to develop our model further in order to generalize the results, as well as more finely grained research related to geography and size might be pursued. Future empirical research is necessary to identify and test the relationships between other constructs and study their effect on a firm's serviceoriented strategy.

\section{References}

Abdolvand, N., Albadvi, A. and Ferdowsi, Z. (2008), "Assessing readiness for business process reengineering”, Business Process Management Journal, Vol. 14 No. 4, pp. 497-51.

Aier, S., Bucher, T. and Winter, R. (2011), "Critical success factors of service orientation in information systems engineering”, Business and Information Systems Engineering, Vol. 3 No. 2, pp. 77-88.

Alreemy, Z., Chang, V., Walters, R. and Wills, G. (2016), "Critical success factors (CSFs) for information technology governance (ITG)", International Journal of Information Management, Vol. 36 No. 6, pp. 907-916.

Armenakis, A.A. and Bedeian, A.G. (1999), "Organizational change: a review of theory and research in the 1990s", Journal of Management, Vol. 25 No. 3, pp. 293-315.

Armenakis, A.A. and Harris, S.G. (2002). "Crafting a change message to create transformational readiness”, Journal of Organizational Change Management, Vol. 15 No. 2, pp. 169-183. 
Arsanjani, A. (2002), "Developing and integrating enterprise components and services", Association for Computing Machinery, Communications of the ACM, Vol. 45 No. 10, p. 30.

Bagozzi, R.P. and Yi, Y. (1988), "On the evaluation of structural equation models", Journal of the Academy of Marketing Science, Vol. 16 No. 1, pp. 74-94.

Baldwin, C.Y. and Clark, K.B. (1997), "Managing in an age of modularity", Harvard Business Review, Sept.-Oct., pp. 84-93.

Bassellier, G. and Benbasat, I. (2004), "Business competence of information technology professionals: conceptual development and influence on IT-business partnerships", MIS Quarterly, Vol. 28 No. 4, pp. 673-694.

Becker, J., Knackstedt, R. and Pöppelbuß, J. (2009), “Developing maturity models for IT management”, Business and Information Systems Engineering, Vol. 1 No. 3, pp. 213-222.

Bharadwaj, A., El Sawy, O.A., Pavlou, P.A. and Venkatraman, N. (2013), "Digital Business Strategy: toward a next generation of insights", MIS Quarterly, Vol. 37 No. 2, pp. 471-482.

Bieberstein, N., Bose, S., Walker, L. and Lynch, A. (2005). "Impact of service-oriented architecture on enterprise systems, organizational structures, and individuals", IBM Systems Journal, Vol. 44 No. 4, pp. 691-708.

Buhl, H.U. and Weinhardt, C. (2009), "Editorial 6/2009: BISE's responsibility in service research", Business and Information Systems Engineering, Vol. 1 No. 6, p. 405.

Cherbakov, L., Galambos, G., Harishankar, R., Kalyana, S. and Rackham, G. (2005), "Impact of service orientation at the business level", IBM Systems Journal, Vol. 44 No. 4, pp. 653-668, available at: http://journals.sagepub.com/author/Castanias $\% 2 \mathrm{C}+$ Richard $+\mathrm{P}$.

Ciarli, T., Meliciani, V. and Savona, M. (2012), "Knowledge dynamics, structural change and the geography of business services", Journal of Economic Surveys, Vol. 26 No. 3, pp. 445-467.

Conboy, K. (2009), "Agility from first principles: reconstructing the concept of agility in information systems development", Information Systems Research, Vol. 20 No. 3, pp. 329-354.

Deloitte GBS (2018), Future of Global Business Services: Catalyst for Enterprise Digital Transformation, available at: https:/www2.deloitte.com/us/en/pages/operations/articles/globalbusiness-services-digital-transformation.html.

Demirkan, H., Goul, M. and Brown, G.W. (2007), "Minitrack: towards 'the service-oriented enterprise”, Proceedings of the 40th Annual Hawaii International Conference on System Sciences (HICSS 07), IEEE, Hawaii, pp. 62-62.

Demirkan, H., Kauffman, R.J., Vayghan, J.A., Fill, H.G., Karagiannis, D. and Maglio, P.P. (2008), "Service-oriented technology and management: perspectives on research and practice for the coming decade", Electronic Commerce Research and Applications, Vol. 7 No. 4, pp. 356-376.

Eichengreen, B. and Gupta, P. (2012), "The two waves of service sector growth”, Working Paper Series No. 14968, National Bureau of Economic Research (NBER), Cambridge, MA.

Ein-Dor, P. and Segev, E. (1978), "Organizational context and the success of management information systems”, Management Science, Vol. 24 No. 10, pp. 1064-1077.

Fornell, C. and Larcker, D.F. (1981), "Evaluating structural equation models with unobservable variables and measurement error", Journal of Marketing Research, Vol. 18 No. 1, pp. 39-50.

Fremantle, P., Weerawarana, S. and Khalaf, R. (2002), "Enterprise services: examining the emerging files of web services and how it is integrated into existing enterprise infrastructures", Communications of the ACM, Vol. 45 No. 10, pp. 77-82.

Gefen, D. and Straub, D. (2005), "A practical guide to factorial validity using PLS-graph: tutorial and annotated example”, Communication of the Association for Information Systems, Vol. 16 No. 5, pp. 91-109.

Hair, J.F., Ringle, C.M. and Sarstedt, M. (2011), "PLS-SEM: indeed, a silver bullet”, Journal of Marketing Theory and Practice, Vol. 19 No. 2, pp. 139-152.
Revitalization of service orientation 
BPMJ 27,8

Hair, J.F., Sarstedt, M., Ringle, C.M. and Mena, J.A. (2012), "An assessment of the use of partial least squares structural equation modeling in marketing research", Journal of the Academy of Marketing Science, Vol. 40 No. 3, pp. 414-433.

Hair, J.F., Hult, G.T.M., Ringle, C. and Sarstedt, M. (2016), A Primer on Partial Least Squares Structural Equation Modeling (PLS-SEM), Sage publications, Thousand Oaks, CA.

Henseler, J., Ringle, C.M. and Sarstedt, M. (2015), “A new criterion for assessing discriminant validity in variance-based structural equation modeling", Journal of the Academy of Marketing Science, Vol. 43 No. 1, pp. 115-135.

Hofstede, G. (1998), “Attitudes, values and organizational culture: disentangling the concepts", Organization Studies, Vol. 19 No. 3, pp. 477-493.

Holmlund, M., Kowalkowski, C. and Biggemann, S. (2016), "Organizational behaviour in innovation, marketing, and purchasing in business service contexts: an agenda for academic inquiry", Journal of Business Research, Vol. 69 No. 7, pp. 2457-2462.

Holt, D.T., Armenakis, A.A., Harris, S.G. and Feild, H.S. (2007), "Toward a comprehensive definition of readiness for change: a review of research and instrumentation", in Pasmore, W.A. and Woodman, R.W. (Eds), Research in Organizational Change and Development, Elsevier, Oxford, Vol. 16, pp. 289-336.

Homburg, C., Hoyer, W.D. and Fassnacht, M. (2002), "Service orientation of a retailer's business strategy: dimensions, antecedents, and performance outcomes", Journal of Marketing, Vol. 66 No. 4, pp. 86-101.

Hulland, J. (1999), "Use of partial least squares (PLS) in strategic management research: a review of four recent studies", Strategic Management Journal, Vol. 20 No. 2, pp. 195-204.

Izza, S. (2009), "Integration of industrial information systems: from syntactic to semantic integration approaches", Enterprise Information Systems, Vol. 3 No. 1, pp. 1-57.

Janssen, M. (2008), "Exploring the service-oriented enterprise: drawing lessons from a case study", Proceedings of the 41st Annual Hawaii International Conference on System Sciences, HICSS, IEEE, Hawaii, p. 101.

Janssen, M. and Joha, A. (2008), "Emerging shared service organizations and the service-oriented enterprise: critical management issues", Strategic Outsourcing: An International Journal, Vol. 1 No. 1, pp. 35-49.

Karmarkar, U. (2004), "Will you survive the services revolution?", Harvard Business Review, Vol. 82 No. 6, pp. 100-107.

Kline, R.B. (2011), Principles and Practice of Structural Equation Modelling, Guilford Press, New York, NY.

Kotlarsky, J. and Oshri, I. (2005), "Social ties, knowledge sharing and successful collaboration in globally distributed system development projects", European Journal of Information Systems, Vol. 14, pp. 37-48.

KPMG Insights (2019), Global Business Services at a Crossroads: Results from the KPMG/HFS Research State of Operations Survey, Boston (accessed 15 November 2019) .

Lacity, M.C., Khan, S.A. and Yan, A. (2017), "Review of the empirical business services sourcing literature: an update and future directions", Outsourcing and Offshoring Business Services, Palgrave Macmillan, Cham, pp. 499-651.

Lee, J.N. (2001), “The impact of knowledge sharing, organizational capability and partnership quality on IS outsourcing success", Information and Management, Vol. 38 No. 5, pp. 323-335.

Luo, Y., Wang, S.L., Zheng, Q. and Jayaraman, V. (2012), "Task attributes and process integration in business process offshoring: a perspective of service providers from India and China", Journal of International Business Studies, Vol. 43 No. 5, pp. 498-524.

Lytle, R.S. and Timmerman, J.E. (2006), "Service orientation and performance: an organizational perspective", Journal of Services Marketing, Vol. 20 No. 2, pp. 136-147. 
MacKenzie, S.B. and Podsakoff, P.M. (2012), "Common method bias in marketing: causes, mechanisms, and procedural remedies", Journal of Retailing, Vol. 88 No. 4, pp. 542-555.

Martin, S.F., Beimborn, D., Parikh, M.A. and Weitzel, T. (2008), "Organizational readiness for business process outsourcing: a model of determinants and impact on outsourcing success", Proceedings of the 41st Hawaii International Conference on System Sciences, Hawaii.

Menor, L.J. and Roth, A.V. (2007), "New service development competence in retail banking: construct development and measurement validation", Journal of Operations Management, Vol. 25 No. 4, pp. 825-846.

Murray, J.Y., Kotabe, M. and Westjohn, S.A. (2009), "Global sourcing strategy and performance of knowledge-intensive business services: a two-stage strategic fit model", Journal of International Marketing, Vol. 17 No. 4, pp. 90-105.

Ojala, A. and Tyrväinen, P. (2007), "Market entry and priority of small and medium-sized enterprises in the software industry: an empirical analysis of cultural distance, geographic distance, and market size", Journal of International Marketing, Vol. 15 No. 3, pp. 123-149.

Orlikowski, W.J. (2002), "Knowing in practice: enacting a collective capability in distributed organizing", Organization Science, Vol. 13 No. 3, pp. 249-273.

Overby, E., Bharadwaj, A. and Sambamurthy, V. (2006), "Enterprise agility and the enabling role of information technology", European Journal of Information Systems, Vol. 15 No. 2, pp. 120-131.

Podsakoff, P.M., MacKenzie, S.B., Lee, J.Y. and Podsakoff, N.P. (2003), "Common method biases in behavioral research: a critical review of the literature and recommended remedies", Journal of Applied Psychology, Vol. 88 No. 5, pp. 879-903.

Prikladnicki, R. and Audy, J.L.N. (2012), "Managing global software engineering: a comparative analysis of offshore outsourcing and the internal offshoring of software development", Information Systems Management, Vol. 29 No. 3, pp. 216-232.

Rai, A., Keil, M., Hornyak, R. and WüLlenweber, K. (2012), "Hybrid relational-contractual governance for business process outsourcing”, Journal of Management Information Systems, Vol. 29 No. 2, pp. 213-256.

Ringle, C., Wende, S. and Will, A. (2005), SmartPLS 2.0 (Beta), Hamburg, available at: www.smartpls.de.

Rönkkö, M. and Evermann, J. (2013), "A critical examination of common beliefs about partial least squares path modeling", Organizational Research Methods, Vol. 16 No. 3, pp. 425-448.

Teece, D.J., Pisano, G. and Shuen, A. (1997), "Dynamic capabilities and strategic management", Strategic Management Journal, Vol. 18 No. 7, pp. 509-533.

Teo, T.S., Srivastava, S.C. and Jiang, L. (2008), "Trust and electronic government success: an empirical study", Journal of Management Information Systems, Vol. 25 No. 3, pp. 99-132.

Umar, A. (2005), "IT infrastructure to enable next generation enterprises", Information Systems Frontiers, Vol. 7 No. 3, pp. 217-256.

Van der Aalst, W.M.P. (2012), "A decade of business process management conferences: personal reflections on a developing discipline", in Barros, A., Gal, A. and Kindler, E. (Eds), Business Process Management, LNCS 7481, Springer-Verlag Berlin Heidelberg.

Van der Aalst, W.M.P., Rosemann, M. and Dumas, M. (2007), "Deadline-based escalation in processaware information systems”, Decision Support Systems, Vol. 43 No. 2, pp. 492-511.

Verdú, A.J. and Gómez-Gras, J.M. (2009), "Measuring the organizational responsiveness through managerial flexibility", Journal of Organizational Change Management, Vol. 22 No. 6, pp. 668-690.

Versteeg, G. and Bouwman, H. (2006), "Business architecture: a new paradigm to relate business strategy to ICT", Information Systems Frontiers, Vol. 8 No. 2, pp. 91-102.

Wang, W.T. and Hou, Y.P. (2015), "Motivations of employees' knowledge sharing behaviours: a selfdetermination perspective", Information and Organization, Vol. 25 No. 1, pp. 1-26.

Revitalization of service orientation 
Weill, P. and Ross, J. (2004), IT Governance: How Top Performers Manage IT Decision Rights for Superior Results, Harvard Business School Press, Boston.

Welke, R., Hirschheim, R. and Schwarz, A. (2011), "Service-oriented architecture maturity", Computer, Vol. 44 No. 2, pp. 61-67.

Wirtz, J., Tuzovic, S. and Ehret, M. (2015), "Global business services: increasing specialization and integration of the world economy as drivers of economic growth", Journal of Service Management, Vol. 26 No. 4, pp. 565-587.

Wong, K.K. (2011), "Review of the book handbook of partial least squares: concepts, methods and applications", in Esposito Vinzi, V., Chin, W.W., Henseler, J. and Wang, H. (Eds), International Journal of Business Science and Applied Management, Vol. 6 No. 2, pp. 52-54.

Wynstra, F., Spring, M. and Schoenherr, T. (2015), "Service triads: a research agenda for buyersupplier-customer triads in business services", Journal of Operations Management, Vol. 35, pp. 1-20.

Zhang, Z. (2018), "Organizational culture and knowledge sharing: design of incentives and business processes”, Business Process Management Journal, Vol. 24 No. 2, pp. 384-399.

\section{Corresponding author}

Albert Plugge can be contacted at: a.g.plugge@tudelft.nl 


\section{Appendix}

\begin{tabular}{|c|c|}
\hline Construct & Items \\
\hline \multirow[t]{6}{*}{ Business processes } & BusPro_1: Global Process Management \\
\hline & BusPro_2: Service Management Integration \\
\hline & BusPro_3: Process Owner Responsibilities \\
\hline & BusPro_4: Process Accountability \\
\hline & BusPro_5: Improvement Strategy \\
\hline & BusPro_6: Process Standardization \\
\hline \multirow[t]{4}{*}{ Governance } & Govern_1: Overall Governance \\
\hline & Govern_2: Service Delivery Channel Governance \\
\hline & Govern_3: Cross-Channel Integration - Collaboration Forums \\
\hline & Govern_4: Cross-Channel - Service Agreements \\
\hline \multirow[t]{3}{*}{ Process-aware information systems } & IS_1: Aütomation \\
\hline & IS_2: IT/Business Process Integration \\
\hline & IS_3: IT Innovation \\
\hline \multirow[t]{2}{*}{ Business services } & BusSer_1: Functional scale \\
\hline & BusSer_2: Business Unit and Geographical scope \\
\hline \multirow[t]{5}{*}{ Organizational readiness } & OrgRead_1: Case for Change \\
\hline & OrgRead_2: Readiness \\
\hline & OrgRead_3: Resistance and Buy in \\
\hline & OrgRead_4: Competing Priorities \\
\hline & KSH_1: Global Workforce Planning \\
\hline \multirow[t]{6}{*}{ Knowledge sharing } & KSH_2: Employer of Choice Strategy \\
\hline & KSH_3: Skills Matrix \\
\hline & KSH_4: Learning and Development \\
\hline & KSH_5: Career Development \\
\hline & KSH_6: Staff Retention \\
\hline & KSH_7: Culture \\
\hline \multirow[t]{5}{*}{ SO strategy } & SOS_1: Integration of business services in overall Business Strategy \\
\hline & SOS_2: Investment Strategy \\
\hline & SOS_3: Value Drivers \\
\hline & SOS_4: Transformation Agenda \\
\hline & SOS_5: Executive Commitment \\
\hline
\end{tabular}

Revitalization of service orientation
Table A1.

List of survey items 


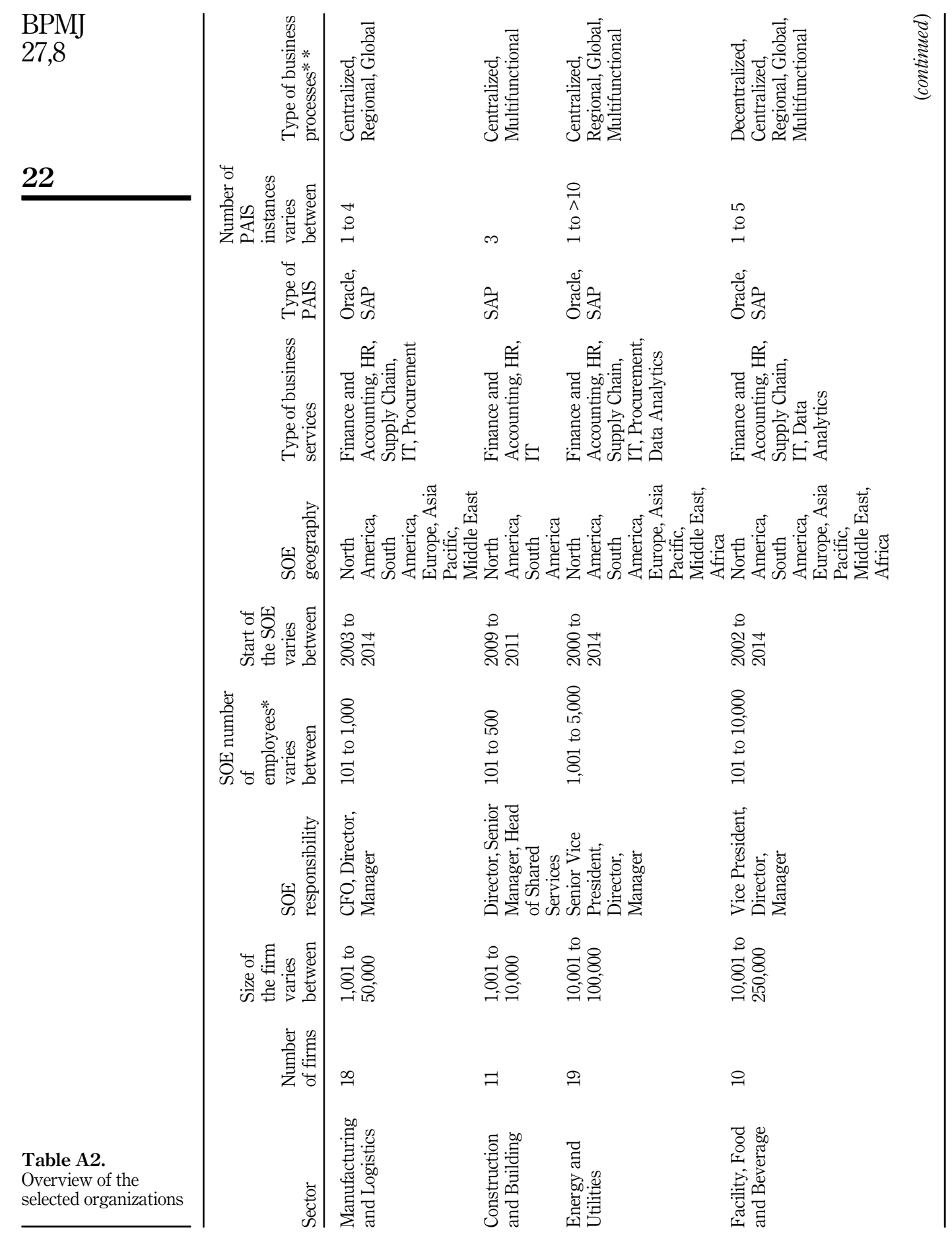




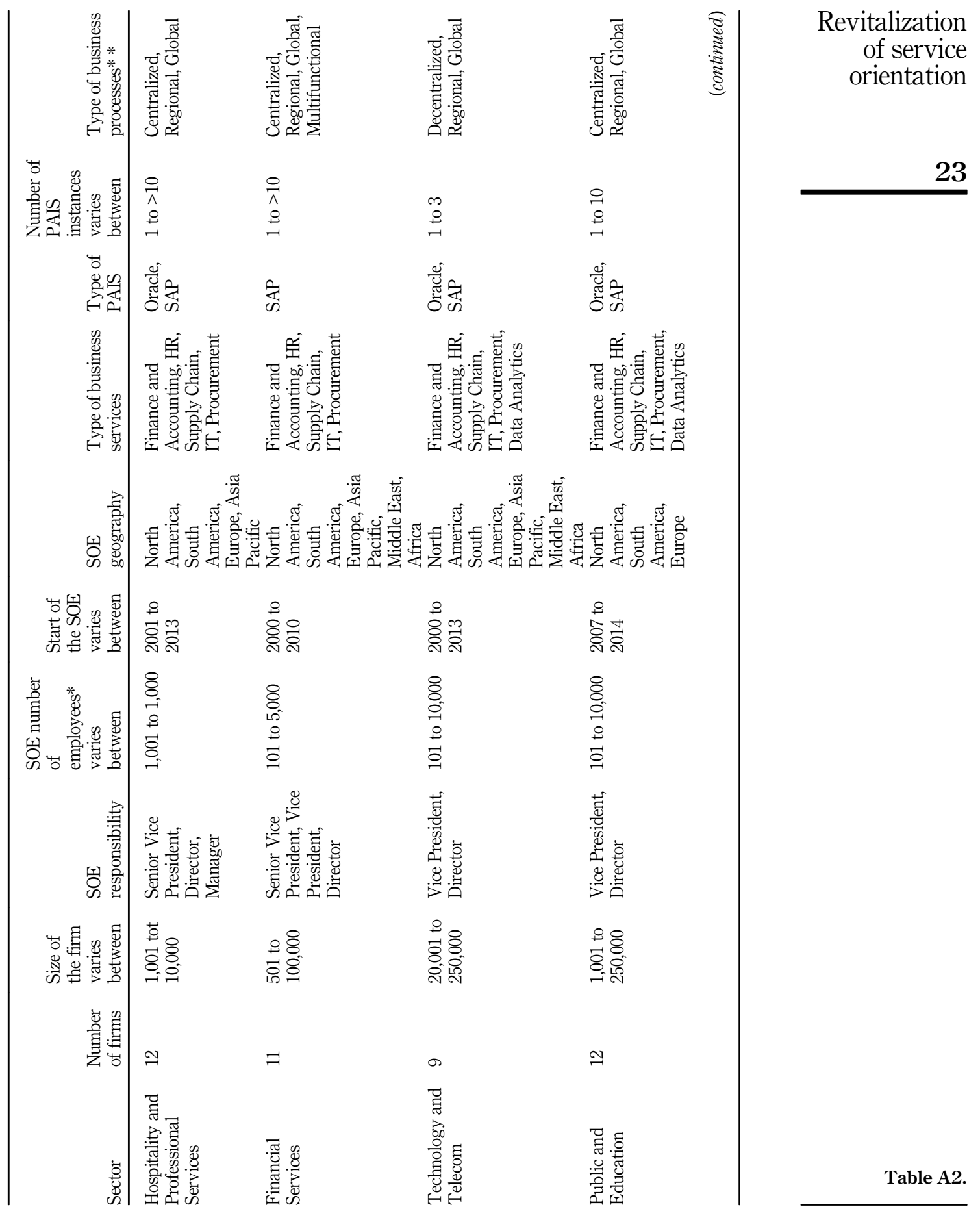




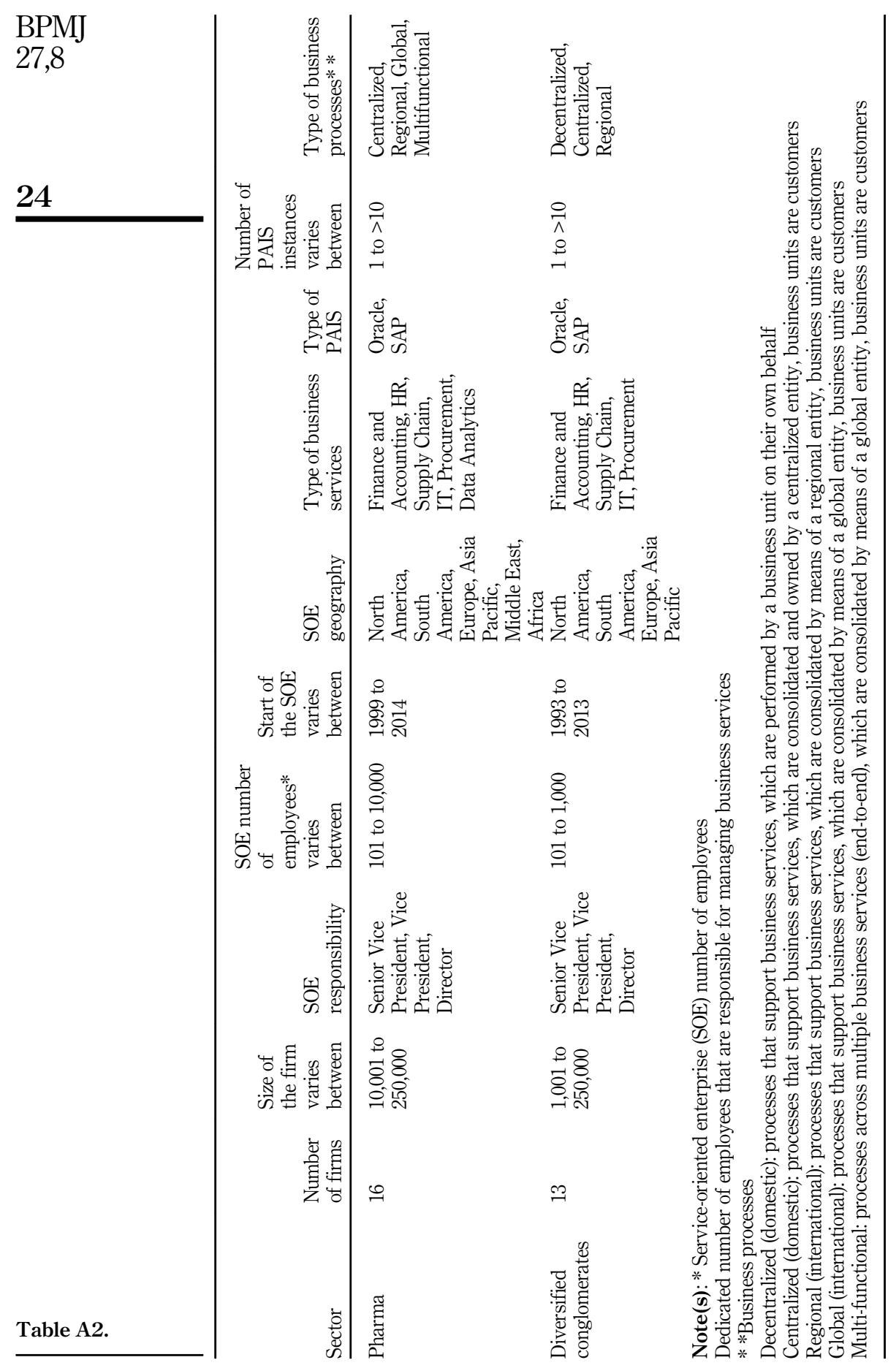

